\title{
ARTICLES
}

\section{CHILDHOOD TRAUMA IN WOMEN AND FRAGMENTED INTERVIEW NARRATIVES - SOME INTERDISCIPLINARY METHODOLOGICAL AND CLINICAL IMPLICATIONS}

\author{
Antonia Bifulco \\ https://orcid.org/0000-0001-8316-9706 \\ Scopus Author ID: $\underline{7003949587}$ \\ a.bifulco@mdx.ac.uk \\ Middlesex University, UK
}

Received April 14, 2021; Revised April 22, 2021; Accepted May 31, 2021

\begin{abstract}
Trauma experience is understood through its expression in language, with implications for psycholinguistic and clinical research and analysis. Clinical research approaches often approach childhood trauma through investigative, semi-structured, retrospective interviews (e.g. Childhood Experience of Care and Abuse, CECA). This facilitates the narration of abuse history for systematic analysis in relation to clinical disorder. Interview techniques assist such history-telling, for example by 'scaffolding' the account, aiding memory through chronological questioning, using a factual focus and using probing questions to collect detail and resolve inconsistencies. However, some personal narratives are fragmented, incomplete, contradictory or highly emotional/dissociated from emotion. This can be explained by trauma impacts such as being emotionally frozen (forgetting and avoidance) or overwhelmed (emotional over-remembering) and is termed 'unresolved trauma' with links to attachment vulnerability. These narratives can make investigative interview research more challenging but can offer opportunities for secondary psycholinguistic analysis. Illustrative interview quotes from CECA childhood physical and sexual abuse narratives of three women are provided with comment on style of reporting. The women had recurrent trauma experience and later life depression and anxiety. The interview responses are examined in terms of seven characteristics taken from available literature (e.g. incoherent, contradictory, lack recall, time lapses, emotionality, blame and vividness). The concept of unresolved loss is discussed and whether the linguistic characteristics are specific to a trauma or to an individual. Factual investigative interviews and psycholinguistic analysis of narrative may find ways of combining for greater depth of understanding of unresolved trauma, to extend available methods and aid therapy.
\end{abstract}

Keywords: CECA interviews, childhood abuse, attachment, unresolved trauma, methods, attachment style.

Біфулко Антонія. Дитяча травма у жінок і фрагментовані наративні інтерв'ю: прикладні міждисциплінарні методологічні та клінічні аспекти.

Анотація. Травматичний досвід може бути виражений засобами мови, що дає змогу його вивчати у психолінгвістичних і клінічних дослідженнях. У клінічних дослідженнях часто застосовують підхід, базований на дитячій травмі із використанням діагностичних, напівструктурованих, ретроспективних інтерв’ю (наприклад, CECA - Childhood Experience of

(C) Bifulco, Antonia, 2021. This is an Open Access article distributed under the terms and conditions of the Creative Commons Attribution 4.0 International Licence (http://creativecommons.org/licenses/by/4.0).

East European Journal of Psycholinguistics, 8(1), 12-27. https://doi.org/10.29038/eejpl.2021.8.1.bif 
Care and Abuse). Підхід, базований на дитячій травмі, полегшує виклад історії скривдження, яка пов'язана з клінічним розладом. Техніки інтерв'ювання допомагають вербально виразити травматичний досвід, наприклад, шляхом «розмотування» ситуації, згадування за допомогою хронологічного опитування, використання фактичного фокусу та пробних запитань для збору даних та з'ясування суперечливих фактів. Однак деякі особисті розповіді фрагментовані, неповні, суперечливі, сильно емоційні, чи навпаки, беземоційні. Це можна пояснити наслідками травми, такими як емоційне оніміння (забуття та уникнення) або переповнення емоціями (емоційне надмірне запам'ятовування), що називається «непропрацьованою травмою» 3 елементами тривожно-амбівалентною прив'язаності. Ці наративи/розповіді можуть значно ускладнити аналіз дослідницьких інтерв'ю, але водночас здатні забезпечити можливість вторинного психолінгвістичного аналізу. Стаття містить ілюстративні цитати 3 розповідей трьох жінок про фізичні та сексуальні скривдження у дитинстві на основі методу CECA із коментарями щодо стилю наративу. Жінки пережили повторювану багаторазову травму, що згодом у дорослому житті спричинило депресію та тривогу. Відповіді під час інтерв'ю аналізуються 3 урахуванням семи критеріїв, узятих із наявної літератури (наприклад, незв'язність, суперечливість, нездатність до згадування, період часу, емоційність, звинувачення та яскравість спогадів). Обговорюється поняття непропрацьованих втрат і те, чи є мовні критерії специфічними для травми чи для окремої людини. Фактичні інтерв'ю та психолінгвістичний аналіз наративів можна поєднати для глибшого розуміння невирішеної травми, а також розширення арсеналу наявних методів та допоміжної терапії.

Ключові слова: інтерв'ю СЕСА, скривдження дитини, прив'язаність, непропрацьована травма, методи, тип прив'язаності.

\section{Introduction}

There is increasing awareness that childhood trauma is a major public health issue (Felitti, 2002). This is due both to its high prevalence (e.g.: 1 in 5 UK adults) (ONS, 2020) and its substantial relationship to later life clinical disorder (Infurna et al., 2016) and physical illness (Dong et al., 2004). There is a real need to understand a person's childhood experience in order to predict their future health risks. There are many ways to achieve this through standardised questionnaire and interview approaches. However recent studies indicate some unreliability due to biases in selfreport measurement (Newbury et al., 2018) and poor memory and traumatic avoidance of recognising the experience (Reuben et al., 2016). Whilst interviews are deemed the most reliable tool (Baldwin, Reuben, Newbury, \& Danese, 2019), these also require careful probing of childhood narrative to establish the sequence, severity and context of key experiences for reliable categorisation. Thus, the individual's ability to communicate their experience is critical for determining facts about what occurred. This is also important for optimising personal interpretations and resolution, such as occurs in narrative therapy (Neuner, Schauer, Klaschik, Karunakara, \& Elbert, 2004).

Those studying and treating early life developmental disorders argue that when trauma is unresolved, narratives can become fragmentary, incomplete and either devoid of emotion or overwhelmed by it (van der Kolk, Pelcovitz, Roth, Mandel, \& et al., 1996). This is in part because of the fear still present in revisiting the threatening experiences. This occurs in Post-Traumatic Stress Disorder (PTSD) 
where avoidance of thinking of the experience with blocking out all references to it, can occur with 'presentification' of the trauma and 'over-remembering' as experienced in flashbacks and nightmares (APA, 2013). Van der Kolk's study of 76 people who were interviewed for either their trauma experience or other positive experience were asked about sensory details, vividness of imagery recall, and emotional response (van der Kolk, 2015). The two sets of accounts were found to be very different. The trauma accounts were found to be disorganised, some details remembered all too clearly, but others such as the sequence of events or some vital details not recalled. The trauma individuals reported experiencing flashbacks and felt overwhelmed by images, sounds, sensations and emotions about the trauma. All the participants with trauma had been unable to tell anyone at the time precisely what happened. Over time they had begun to make sense of the experience and know more about what happened by piecing together the details and sequence of events and were then able to tell others. In this study $85 \%$ were able finally to tell a coherent story with only few missing details although five abused as children still retained the most fragmented memories (van der Kolk, 2015).

Psycholinguistic investigations of trauma narratives, from the seminal work of Pennebaker (1993), have linked characteristics such as verbal emotional expression, increasing use of insight, causal and associated cognitive words to be indicative of health (Pennebaker, 1993). This has been studied by means of the Linguistic Inquiry and Word Count (LIWC) text analysis programme (Francis \& Pennebaker, 1992). This method has been used in a range of autobiographical narratives which include interviews, diary studies, life stories and word cue methods usually in non-clinical samples (Zasiekina, Kennison, Zasiekin, \& Khvorost, 2019). For example, a comparison of trauma and positive experiences in the written narratives of 61 nonclinical respondents used LIWC to look at psycholinguistic markers for autobiographical memory (Zasiekina et al., 2019). The presence of negative emotions and anxiety and the use of the pronoun 'they' as an external agent of proposition were higher in trauma memories as were categories of time and space. Conversely, a lower word count and a focus on the present was more common in the trauma narratives. Given the participants were free from PTSD, the fact the narratives were not stuck in time or overestimating of the trauma, was taken as protective of PTSD (Zasiekina et al., 2019). The presence of social categories also pointed to an important positive impact of social support.

The approach attending to word count particularly has been applied more to non-clinical samples and to particular free written or speech tasks. Another approach has examined 'language injury' as apparent in the interviews of respondents with clinical disorder describing trauma experiences, for example in an interview study of 15 war-traumatised patients with PTSD (Auxéméry, 2020). The narratives showed lexical poverty and traumatic anomia (marked hesitation and inhibition of speech), linguistic repetition of signifiers of the event (together with verbal intrusions, repetition of filler words), and discursive disorganisation (verb tenses telescoped, reliving the event, lack of future reference, incomplete sentences) (Auxéméry, 2020). These discourse characteristics linked to trauma were termed 
'language injury'. Similar effects have also been shown in a study of 28 young Africans who were refugees and unaccompanied minors aged 14-18 when compared to a case controlled high school group (Huemer et al., 2016). The 10minute, uninterrupted speech task focused first on the respondent's most stressful event and second on any topic that came to mind. These were recorded and analysed by word count, linguistic narrative (temporal junctures/sequencing), narrative structure (avoidance of description, absence of emotion, lack of comprehensible form), referential activity (sensory and emotional expressivity) and content analysis (type of trauma event). In the traumatised youth the stressfulness of events (ie trauma exposure) were significantly higher, with significantly lower word count in the narratives and increased referential activity in both tasks. However, there was no difference in the number of temporal junctures, nor the number of stories related between the groups. The authors point to this approach as showing more subtle indicators of traumatisation than conventional checklist methods. The approach has also been tested in 67 children (aged 7-16 years) who experienced a physical trauma involving hospitalisation who were tested over 3 months (McKinnon, Brewer, Meiser-Stedman, \& Nixon, 2017). The children were asked at interview to produce a narrative about the traumatic accident as well as completing questionnaires about trauma memory, acute stress PTSD symptoms with a focus on the sensory, fragmented and disorganised characteristics of trauma memory exhibited (McKinnon et al., 2017). Findings showed that trauma memory quality was implicated in the aetiology of symptoms (acute stress and PTSD) with trauma narrative memory implicated specifically in PTSD. Over time there was a reduction in the children's fragmentary narratives with high sensory experiences in line with their stress scores. The study indicates that perception of trauma memory are a driver of symptoms and that positive change can occur in both.

The method has also been used in older age groups to examine psycholinguistic markers of mental trauma and PTSD involving past collective trauma events. Thus, Zasiekina examined trauma narratives in survivors (aged 75+) of the Ukrainian Holodomor, a starvation genocide in Stalinist times of the 1930s. The study used LIWC analysis and categories of time, 'I' and cognitive processes in relation to word count for traumatic memory (Zasiekina, 2020). Findings showed poorer reappraisal of events and an overestimation of time as predictive of word count in multiple regression. Given the historical knowledge of the collective trauma experience the principle of 're-memory' or 'dis-memory' as a narrative strategy for individuals articulating trauma experience which is 'unspeakable' and impossible to narrate is invoked (Nikro, 2019). Reconstructing the distorted episodes of traumatic experience can thus occur in a historical context and aids to recall may be beneficial for mental health.

The concept of unresolved childhood trauma is most often applied to experiences of neglect or abuse and taken as an element in understanding disrupted attachment processes (Main \& Hesse, 1990). Attachment frameworks provide a model of understanding the impact of childhood trauma on adult functioning through multiple mediational links including distorted cognitive templates (Collins 
\& Read, 1990), emotional dysregulation and mentalisation (Fonagy, Gergely, Jurist, \& Target, 2002), and barriers to disclosure and relating ability (Bifulco \& Thomas, 2012). Use of language is also implicated in attachment style problems in some approaches (Main \& Hesse, 1990) compromising coherence of accounts and contravening Grice's maxims of conversational coherence (Grice, 1989; Hesse, 2008). The Grice maxims required for good communication involve the principles of quality (truthfulness and evidence); quantity (succinct and complete); relation (relevance) and manner (clear and orderly).

In the Adult Attachment Interview (AAI) (George, Kaplan, \& Main, 1984) respondents are asked about childhood experience, and the qualities of the audiorecorded and carefully transcribed narration are scrutinised to establish narrative patterns believed to indicate adult attachment styles. Thus coherence indicates secure style, in contrast idealisation of attachment figures, insistence on lack of memory and derogating attachment experiences indicate dismissing or avoidant attachment whilst anger expressed or vagueness in discourse indicate preoccupied or anxious-ambivalent style) (Hesse, 2008). In addition to these 'organised' styles, disorganised or 'cannot classify' categories relate to unresolved loss or abuse with 'lapses of monitoring of reasoning or discourse' or 'prolonged silence or eulogistic speech' (p 571) (Hesse, 2008). These can be specific to description of loss or abuse when it occurs in the interview. The AAI explicitly aims to 'surprise the unconscious' through open questions and to elicit verbal errors to elucidate underlying affective-cognitive processing (Main, Kaplan, \& Cassidy, 1985). While childhood events and relationships are typically scored, their factual accuracy have a lesser role in the measurement system.

This is in contrast to investigative interview methods designed to elicit an accurate account of childhood trauma events. Thus the Childhood Experience of Care and Abuse (Bifulco \& Moran, 1998) is a factually orientated retrospective interview which uses a semi-structured format with probing questions to aid the respondent in recalling and ordering events. This is undertaken by explaining the scope of the interview, by taking a chronological approach to childhood events, by asking questions such as about a 'typical day' in childhood and for seeking greater detail of events reported. Thus, when abuse is recalled, the respondent is asked at what age it occurred, from whom, how often and over what period of time. The respondent is also encouraged to give a full description of the event. It is only through such an account that the severity of the experience can be gauged and scored. Many respondents can do this readily with minimal additional probing required. But for others it is difficult, and the interviewer may have to use skilful probing, or return to the topic later in the interview, or be satisfied with an incomplete rendition. Many such respondents find the factual and direct questions easier to respond to (e.g. 'How old were you at the time?' 'Who did it to you?' 'How often did it happen?') rather than indirect open questions (e.g. 'Did you have a difficult childhood?'). It is not necessary for the respondent to visit the emotion of the experience to provide sufficient information for CECA scoring. 
This paper seeks to explore links between selected investigative child abuse interview accounts using the CECA and a psycholinguistic approach involving identified characteristics of speech associated with trauma, to see if there is future potential for combining approaches in a systematic way. Sections from three childhood interview transcripts of severe childhood abuse (physical or sexual) which constitute trauma experience are examined to illustrate seven characteristics of psycholinguistic properties or reporting styles. These include incoherence, contradictoriness, lack of recall, emotional response, time lapses, blame and vividness. The transcripts are taken from an existing data set, where the quantitative data has been previously published to show childhood abuse is a significant predictor of adult insecure attachment style and major depression (Bifulco, Brown, Lillie, \& Jarvis, 1997; Bifulco \& Thomas, 2012). However, the qualitative aspects of the interview narrative have not been analysed before and are newly described here. All relevant ethical permissions were given at the time of the original study from health services with informed signed consent by participants.

\section{Method}

Three childhood interviews were selected from a large data base of 303 with community women initially selected through screening questionnaires to London general practices (Bifulco, Bernazzani, Moran, \& Ball, 2000). This did not constitute a clinical sample per se, although many had experienced adult clinical depression or anxiety disorder. The interview extracts transcribed were ones with unusual reporting characteristics and had served as illustrative case studies or training for interviewers (Bifulco \& Moran, 1998; Bifulco \& Thomas, 2012).

The Childhood Experience of Care and Abuse (CECA) interview is a standardised semi-structured interview to establish factual accounts of neglect and varied abuse before age 17 (Bifulco \& Moran, 1998). It has high reliability and validity as determined by comparison of sister interviews (Bifulco et al., 1997). It focuses on the severity of abuse according to predetermined criteria as well as details of age, duration, relationship to perpetrator. Extracts from CECA interview transcripts are used here to illustrate some psycholinguistic characteristics of reporting trauma. These are shown below with ' $Q$ ' for interviewer questions and ' $A$ ' for respondent answers, and the dotted lines represent hesitations, pauses or incomplete sentences. Occasionally tone of voice is mentioned from the audiorecording but the main focus is on the transcribed verbal material.

In addition to the CECA, the life history interviews also covered adult attachment style using the Attachment Style Interview (ASI) (Bifulco \& Thomas, 2012) to determine Secure, Anxious (Enmeshed or Fearful), Avoidant (Angrydismissive or Withdrawn) or Disorganised (mixed insecure) styles at time of interview. Lifetime clinical depression or anxiety states were also measured using a clinical interview (Structured Clinical Interview for DSM-IV, SCID) (First, Gibbon, Spitzer, \& Williams, 1996). Each of the three women selected had more than the one trauma in childhood, all had at least one adult trauma and all experienced 
recurrent adult life depression/anxiety and had adult insecure attachment styles. The trauma reporting characteristics cannot therefore be used to suggest different clinical or vulnerability outcomes.

\section{Categories utilised}

A pragmatic approach was taken, linking features of the interview narratives to those identified in existing clinical studies of the psycholinguistics of trauma in terms of language injury or incoherence. The definitions of these are shown in table 1 , as understood by the author, with reference to related sources.

\section{Table 1}

\section{Characteristics of childhood trauma interview narratives}

\begin{tabular}{|c|c|c|}
\hline $\begin{array}{c}\text { Characteristic } \\
\text { assessed }\end{array}$ & Definition & Related source/study \\
\hline Incoherence & $\begin{array}{l}\text { Incomplete sentences; lack of logical } \\
\text { sequence, at extreme very fragmented } \\
\text { narrative with little content. }\end{array}$ & $\begin{array}{c}\text { Traumatic anomia } \\
\text { (Auxéméry, 2020); Narrative } \\
\text { structure (Huemer et al., } \\
\text { 2016); Trauma memory } \\
\text { quality (McKinnon et al., } \\
\text { 2017); Incoherence (Hesse, } \\
\text { 2008). }\end{array}$ \\
\hline $\begin{array}{l}\text { Contradictory } \\
\text { information or } \\
\text { ambivalence }\end{array}$ & $\begin{array}{c}\text { An illogical example such as 'my } \\
\text { mother favoured me, that's why she hit } \\
\text { me more' or 'I loved my mum but I hated } \\
\text { her'. }\end{array}$ & $\begin{array}{l}\text { Incoherence (Hesse, } \\
\text { 2008). }\end{array}$ \\
\hline Lack of recall & $\begin{array}{l}\text { Repetition of comments like 'I can't } \\
\text { remember' with gaps in the account. }\end{array}$ & $\begin{array}{c}\text { Traumatic anomia } \\
\text { (Auxéméry, 2020); Trauma } \\
\text { memory quality (McKinnon } \\
\text { et al., 2017); Avoidance } \\
\text { (Hesse, 2008). }\end{array}$ \\
\hline $\begin{array}{c}\text { Time } \\
\text { lapses/temporal } \\
\text { processing }\end{array}$ & $\begin{array}{l}\text { Transferring from past to present } \\
\text { examples in answer to the question } \\
\text { without full explanation (eg mother } \\
\text { argued with me - like she did last } \\
\text { week....). }\end{array}$ & $\begin{array}{l}\text { Past referents (Zasiekina, } \\
\text { 2020); Temporal junctures } \\
\text { (Huemer et al., 2016); } \\
\text { Incoherence (Hesse, 2008) }\end{array}$ \\
\hline Emotionality & $\begin{array}{l}\text { Distress, fear or anger indicated in the } \\
\text { narrative. This can be through language } \\
\text { used (thinking she was going to be killed) } \\
\text { or angry language with cursing etc. }\end{array}$ & $\begin{array}{c}\text { Referential activity } \\
\text { (Huemer et al., 2016); } \\
\text { Emotionality ( van der Kolk, } \\
\text { 2015). }\end{array}$ \\
\hline Blame & $\begin{array}{l}\text { Attributing the abuse to self or other } \\
\text { often accompanied by report of guilt or } \\
\text { anger. }\end{array}$ & $\begin{array}{c}\text { External referents } \\
\text { (Zasiekina, 2020); } \\
\text { Derogating attachments } \\
\text { (Hesse, 2008) }\end{array}$ \\
\hline $\begin{array}{c}\text { Vividness/ event \& } \\
\text { dialogue reconstruction }\end{array}$ & $\begin{array}{l}\text { the account is graphic and seems 'in } \\
\text { the moment'. Dialogue of the event } \\
\text { reproduced instead of summarised. }\end{array}$ & $\begin{array}{l}\text { Discursive disorganisation } \\
\text { (Auxéméry, 2020; van der } \\
\text { Kolk, 2015). }\end{array}$ \\
\hline
\end{tabular}




\section{Results}

Excerpts of trauma narrative from interviews are provided below with subsequent identification of key characteristics for each extract, these are then summarised together at the end of the section.

\section{Amanda's physical abuse}

Amanda was brought up by both parents and experienced neglect, emotional and physical abuse from her mother from earliest years. She explains it by her mother's mental illness and heavy drinking, which she says led to unprovoked violence. She is close to her mother now, was concerned that no blame should be attached to her mother and expressed no anger towards her. They are still in close contact.

She describes the worst incidence of physical abuse from her mother:

A I was about 8, I think, I was sitting at the kitchen table and she'd asked me a question, and I remember answering it and she said to me 'You mumbled' and I said 'I never mumbled' and she said 'Don't answer me back' and she hit... was hitting me, literally and I was on the floor trying to hide under something and my dad happened to walk in and he had to hit her, to stop her hitting me,....but I remember begging my mum to stop but she just wouldn't, I just don't think she realised that she was hitting a child, I think she thought... I don't even know what she thought at the time, but I don't think that she knew that she was hitting a child. And my dad said, you know 'For God's sake, can't you hear that child, she's begging you to stop.' And after that it wasn't.... she would just hit the once after that, I think she realised....

Q Do you think that was the worst one in terms of how badly you were hurt?

A That was the worst one I can ever recall, you know, actually begging her to stop... I was hiding, I was trying to find....

Q Was she hitting you with her hand?

A Anything, anything she could get her hands on... and I remember her having this knife and I remember her throwing it at me at first and she caught me, and I thought 'Oh God, she's gonna kill me', you know, and I was trying to hide, but she was...

Q Was that the same occasion, that she threw the knife?

A No, she did it a couple of times, she would just throw it just to shut us up more than anything....

Q Did you get badly hurt, did you have to go to the doctor or hospital?

A No, no, it was just like a little prick and then it would fall out. I think it was just the shock more than, you know....' Oh God, my mum's stabbed me' sort of thing you know. But that was the worst one - it still plays on my mind that, you know, the fact that she.... wherever I tried to hide she just kept on...it was even as if she'd had a brainstorm or something, she just kept on hitting...

Amanda related this event vividly with considerable emotion as though reliving it. The narrative has incomplete sentences, and she repeated the issue of begging her mother to stop. She says it 'still plays on her mind'. She provides some context, such as her father intervening, but then goes on to merge the incident with another when her mother, in temper, threw a small kitchen knife at her, without clarifying this was another occasion. Amanda downplays the significance of that incident by 
saying it was just shock not being hurt that was an issue, but implies the knife incident happened more than once. She later expressed some contradictions about her mother, for example saying that she knew she was her mother's favourite because she was hit her more often than her siblings. She attributes both responses to her 'cheekiness' (insolence). Thus the account indicates some incoherence, contradictory elements, emotionality and vividness. There was no evidence of lack of recall, time lapses or blame.

In contrast later in the interview Amanda describes a sexual abuse attempt when she was aged 10 and ill in hospital. This narrative has greater clarity and it is perhaps significant that she took control in the situation to reduce the trauma exposure:

... once I had an experience when I was in hospital. There was this man who was going round abusing the children and he came into my room and he told me he was a vicar, and he was talking to me and he kept asking me if he could tickle me, and I kept saying: 'no, you mustn't do that'. Because my dad had already explained that there were dirty old men and I said 'no, you mustn't do that', and I got a bit frightened. And then he left, for some reason, you know, he never ever touched me but apparently he had got frightened and he had left, because I'd rung the bell (for the nurse). Then when my dad and mum came that night to see me I explained to them what happened and my dad - well, if he'd got hold of the man I know he would have killed him. And apparently when the police came they said that out of all the children on the ward, I was the only one that he hadn't abused.

Her father contacted the police once she disclosed and the perpetrator was apprehended and Amanda was a witness in the court case. She explained that nine younger children had been sexually abused and she was the only one to raise the alarm. She attributes this to the advice her father had given her:

Yeah, I remember my dad had said, you know, 'your body is your body, and nobody touches your body except you, and you know, your mum and dad if we bath you, but other than that your body is your body and you say "no" to anybody".

In comparing the two extracts it should be noted that the physical abuse experience was much more severe. In reporting it there was more emotional content (this also conveyed by tone of voice, and breathless speech) and incomplete sentences with repetitions, vividness and a disjointed link to another incident of abuse by the mother. The second sexual abuse incident seems clearer in comparison and it was one where she was able to take control, to disclose to her father who took action and told the hospital authorities. Amanda was willing to make a statement against the abuser. It could be argued that the second abuse did not constitute trauma (this was averted) and this could account for the greater clarity of the account. This indicates that Amanda has capacity for providing clearer narration and the disturbed reporting was specific to the abuse from her mother.

In adult life Amanda experienced trauma from a partner who was physically and emotionally threatening, eroded her self-esteem and lied to her about his finances and work. She became clinically depressed and anxious after a difficult separation from him. She had also experienced both disorders after an earlier 
separation from her first partner at a difficult time when she was pregnant. She had no symptoms at interview. In terms of vulnerability she had an anxious Enmeshed attachment style with no support and fear of separation and low self-reliance.

\section{Carol's physical abuse}

Carol is aged 36 and lived with both birth parents and her grandmother in childhood and experienced emotional and physical abuse from her mother from earliest years. Her mother was very critical of Carol and would also hit her frequently (around monthly) either with her hands or with an implement such as a belt or stick. Carol describes one such incident:

Q. Did you ever get badly beaten by her?

A. When she gave me a black eye, when 1 was about 15 . I told her, I said to her when I was 15 , 'you ever f***ing hit me again, I tell you, mother or no mother, I'll hit you back... .After that day she never ever hit me... until this day.

Q. How often would she hit you?

A. She'd hit you for anything, you know even.... I remember her one day coming in and somebody had.... a letter was opened. Now I did not .....and I mean I'm.... she still says to me to this day: 'you did open it'. But I didn't open her mail..... I wouldn't want to see what's in her stupid old mail! And she accused me of opening that letter and I said: 'I didn't touch your letter' - 'you did, you opened it. You opened my private business', 'I wouldn't touch your private business!' Anyway, she belted me. She didn't half give me a cuff and that's the day I told her: 'you ever hit me like that again I'll $\mathrm{f}^{* * *}$ ing hit you back, and I don't care, mother or no mother!' She never ever hit me again.

She describes her mother in an angry emotional tone and as 'in the moment' of the event reproducing dialogue. There are repetitions and incomplete sentences. She also later in the interview interspersed her childhood narrative with ongoing descriptions of her mother switching time frames. When later describing her mother's neglect of the children in childhood she described how she spent her days in bed and she switches to a current description to illustrate it, and her account is blaming and angry. She says:

Nothing wrong with her! Still nothing wrong with her, she still goes to bed every afternoon. ...she moans about the housework she's got to do - she's only got her and my dad there. And she moans about the housework still. I mean she's got all day on her hands!

Later she adds: "I love my mum but she's just....she's just too selfish, she's all for her $\mathrm{f}^{* * *}$ ng self!" Therefore, the account shows incoherence, emotionality, vividness, time lapses and blame of other. There is no sign of contradictoriness or lack of recall.

As an adult Carol married and had two children. Her adult trauma experience was when her 12-year old son died accidentally whilst playing on a building site. She experienced chronic grief, guilt and panic disorder, and when the school held a memorial service for him two years later, she became depressed. She had a disorganised attachment style (angry-dismissive and enmeshed). Her mistrust and 
anger to the world was combined with a fear of people leaving her and anxiety over her remaining daughter.

\section{Donna's sexual abuse}

Donna is aged 28 at interview and had a neglectful and chaotic upbringing in relation to changes of household arrangements. Her mother had alcohol dependence, was separated from Donna's father, and had a succession of live-in partners. Donna lived with her siblings including her twin sister Jane. [Her sister was also interviewed in the study and gave a clearer corroborative account of the sexual abuse which she too experienced.]

The sexual abuse began when Donna was aged 8 and lasted over an 18-month period. It was from a male friend of her mother's, for whom she would babysit his children. It seems there were sometimes other adults present during the abuse which involved sexual intercourse. Donna had difficulty speaking about the topic despite being very expressive about other events in her childhood. It was only after describing being raped as an adult by her husband Dave that the interviewer was able to return to question the sexual abuse in childhood. Donna did then describe it, but haltingly, with incomplete sentences, claims of not remembering and with little clarity.

Q Can I ask you about the sexual abuse when you were in Cornwall? Maybe that's the hardest thing for you to talk about.... Why is it so hard? Is it because you were so vulnerable at that time?

A $\quad$....Just wasn't nice, I don't feel....

Q I mean, you're able to talk about Dave (husband) though?

A Yeah...that's probably 'cos it's nearer, I mean it's probably because that one was a long actually a long time ago....you tend to bury it. ........That's er........I don't know - I don't know what the difference is, I suppose with Dave it was because he was my husband and ....

Q But was it a very similar kind of thing, I mean it was forcing sexual intercourse onto you?

A Yeah... yeah... It's... I don't know, perhaps it's because I'd actually said to Dave: 'No, I don't want to sleep with you', therefore perhaps I'd deserved it - I know you don't deserve it, but there's that kind of bent logic to it somewhere, when you actually think back on it...

Q No child of 8 deserves it.

A .... No, but when you're young, you don't deserve it... I think probably that's probably why I find it more difficult... because with Dave I could've walked out...before I did walk out.... with this...there was no choice in it at all, that was it, it was there...

Q Was it just something that you couldn't do anything about?

A It was....er...it was difficult...

Q How often did this happen?

A Whenever I babysat for them.

Q How often was that?

A Which is - about once a week, once a fortnight.......er.... The trouble was with that, was the fact that if I didn't babysit for them, Jane would babysit for them, so....

Q And you didn't know whether it was happening to her?

A No, I think it was, it's just... neither of us ever said anything, but we were so close then I don't think we'd need to say anything...We used to know each other so well...

Q But you thought was happening to her? 
A I thought it was... so if I didn't go then she'd have to go, so... either way, one of us was going to get it, so it....it depends who was feeling stronger at the time, I think, would be the one that would go babysitting.

Q And no-one else had any idea that it was happening?

A No..no...

Q And were you hurt at all?

A Hurt?... I don't know, there's so much of it is blocked out now.... I suppose I must've been hurt...but I don't know how hurt, if that makes sense.... er... It must've hurt when it first happened, I mean, obviously, but I think probably then... It's like having a toothache, isn't it? After a while you get used to the pain, so the tooth doesn't ache so much... the tooth is still aching, but it doesn't actually feel like it's aching so much, so it doesn't matter so much, so you put off going to the dentist, you know........Yeah, it was, it was difficult...... It's difficult because you ... I mean, I knew it was wrong, as well, I knew it was wrong.... but....knowing what to do about something that you knew was wrong was difficult...

Slightly later she said:

Er........It was difficult... I mean, a lot of it is a blur, I mean...I seem to remember once that he had some friends round with him......but I don't think they actually did anything, but I don't remember....It's just - I remember there being other people ---

Q Do you think they might have just watched you?

Possibly......I don't remember. But that - that's probably being selective memory, I don't know..........different occasions, different things........ know it didn't mean a lot, at the end of the day it didn't mean anything...........But now, it still doesn't mean anything now, it's just -it's gone, something that happened..... Makes you more - well, I don't know, I suppose, from a very young age I knew what men liked, let's put it that way! (She laughs wryly). Which probably made me very wary of men in general!

Donna can only provide a very hesitant and incomplete memory of her childhood sexual abuse. This seems to be accompanied by feelings of guilt and self-blame, first because she knew it was wrong, but also because she thinks her sister also suffered it and later she describes liking the affection involved. She is able to compare it to being raped as an adult but explains that as an adult she could take action and walk out, but was unable to do that as a child. She also says dismissively that it had 'no meaning' and was 'gone'.

Donna's account is the most hesitant of the narratives suggesting some 'blockage' of the memory, and shows incoherence, lack of recall and blame of self. There is none of the emotionality evident in the others (in fact rather there is a lack of feeling) nor vividness and she does not fall into time lapses. Yet in some ways it seems the least processed of the narratives.

Donna later was exposed to adult trauma through domestic violence form her husband Dave and suffered clinical depression at that time as well as at another time in her life. Her attachment style at interview was angry-dismissive (with mistrustful and overly self-reliant characteristics).

Summarising all the narrative categories scored (see table 2) it can be seen that each of the trauma narratives (apart from Amanda's sexual abuse) included 35 psycholinguistic characteristics suggestive of lack of trauma resolution. They all had a level of incoherence in the narrative. The two physical abuse excerpts showed 
both emotionality and vividness. In both cases the mother who perpetrated the abuse was still in regular contact with the respondent although only Carol was still angry with her mother and blamed her for the abuse. Her account had the highest number of linguistic characteristics associated with lack of resolution including time lapses. Amanda in contrast felt some conflict of loyalty in reporting her abuse since she felt close to her mother. Of the extracts Donna's account seems the least processed psychologically and was the most difficult to elicit at interview. The abuse was by a stranger and although by implication her mother had some responsibility though her neglect, Donna was not in contact with the perpetrator. There was a particular 'moral injury' here since if she did not make herself to the abuser, she knew that her twin sister would have to. She expressed self-blame but perhaps also felt guilt.

Table 2.

\begin{tabular}{|c|c|c|c|c|c|c|c|c|c|}
\hline Respondent & $\begin{array}{c}\text { Type of } \\
\text { abuse }\end{array}$ & $\begin{array}{l}\text { Incohe } \\
\text { rence }\end{array}$ & $\begin{array}{c}\text { Con- } \\
\text { tradicto } \\
\text { ry } \\
\text { informa } \\
\text { tion }\end{array}$ & $\begin{array}{c}\text { Insists } \\
\text { lack } \\
\text { of } \\
\text { recall }\end{array}$ & $\begin{array}{c}\text { Emoti } \\
\text { on } \\
\text { ality }\end{array}$ & $\begin{array}{c}\text { Vivid } \\
\text { ness/ } \\
\text { dial } \\
\text { ogue }\end{array}$ & $\begin{array}{l}\text { Time } \\
\text { lapses }\end{array}$ & Blame & Total \\
\hline Amanda & Physical & YES & YES & NO & $\begin{array}{r}\text { YES } \\
- \text { fear }\end{array}$ & YES & $\mathrm{NO}$ & $\mathrm{NO}$ & 4 \\
\hline Amanda & Sexual & $\mathrm{NO}$ & NO & NO & NO & NO & NO & NO & 0 \\
\hline Carol & Physical & YES & NO & NO & $\begin{array}{c}\text { YES } \\
- \\
\text { anger }\end{array}$ & YES & YES & $\begin{array}{c}\text { YES } \\
- \text { other }\end{array}$ & 5 \\
\hline Donna & Sexual & YES & NO & YES & NO & NO & NO & $\begin{array}{l}\text { YES } \\
\text { self }\end{array}$ & 3 \\
\hline
\end{tabular}

\section{Discussion}

Examples provided in this exploratory secondary analysis of a child abuse interview data set suggests that there was clear variation in ways of expressing trauma memories of childhood indicative of affective-cognitive or memory disturbance as reflected in reporting language. These have been described utilising psycholinguistic characteristics taken from other trauma research analyses. These were selected first because all were relevant to clinical samples and the transcripts included were of women who had repeated clinical disorder and second because they were relevant/appropriate to the transcripts utilised. This is because the interviews were not undertaken as free speech tasks and so the use of word counts etc harder to apply. All instances (apart from Amanda's minor sexual abuse reporting) had at least three characteristics indicating lack of 'clarity or completeness' as required by Grice's maxim of coherent communication [for principles of quality (truthfulness and evidence); quantity (succinct and complete); relation (relevance) and manner (clear and orderly)] (Grice, 1989). These 
characteristics may be taken to indicate unresolved trauma in the sense of incomplete psychological processing of the memories. However, in the context of a full life history interview this leads to certain questions. For example, whether the speech patterns indicate characteristics of a particular memory (the unresolved trauma event) or are common to other event reporting and a style of speech (disturbed affective-cognitive functioning) or chronic symptomatology (underlying or complex PTSD)? This analysis shows one example (Amanda) of a respondent having a different speech pattern for a different memory but does not make similar comparisons for the other two respondents. It is also unknown to what extent the investigative nature of the interview constrained the style of expression compared to the free speech approaches of other trauma studies described. For this reason a word count was not considered. It maybe that an investigative approach could help individuals to achieve greater clarity, perhaps through repeated interviews. This has yet to be tested.

The illustrative analysis provided has limitations. The selection of interview quotes were not through any systematic methodological process. Also, each respondent had experienced multiple traumas rather than just the one described which makes attribution of language patterns difficult. The quotes only represent a small part of a much longer interview and the categorisation of reporting was only conducted by an eyeballing of the narrative by the author and not through a formal scheme with reliability estimates.

The remaining question highlighted by this analysis is whether incoherence in the accounts indicates unresolved trauma for specific experiences/memories or is indicative of more general developmental damage. This latter is indicated through lasting affective-cognitive vulnerability as mediated for example in insecure attachment style. However, the analysis does suggest that linguistic patterns may provide additional markers of problems in psychological processing which could be accessed relatively quickly. It also raises the question of whether resolving the trauma can be shown through subsequent coherent narrative to indicate an improvement in memory, functioning and even symptoms. This can occur through 'healing relationships' or therapy (Herman, 1992) but maybe aided by repeated interviews of trauma experience to aid expression and remembering of the experience.

\section{Conclusion}

The exploratory aim of the paper was to take sections of trauma narrative from an existing interview data set to re-examine characteristics of the speech style. This was to see if categories used in psycholinguistic research on trauma can be applied to investigative interview material to indicate problem processing of childhood trauma experience. If this is considered viable then further re-analysis of such data sets could provide a new avenue for combining clinical and psycholinguistic approaches to create more refined and varied judgements about trauma resolution. This could lead to greater inter-disciplinary working on trauma for improved 
markers of risk with repeated narrative scrutiny used to indicate improved processing and to aid narrative therapy approaches.

\section{References}

APA. (2013). Diagnostic and Statistical Manual of Mental Disorders (DSM-5®). Arlington, VA: American Psychiatric Association.

Auxéméry, Y. (2020). A new approach to diagnose psychological trauma starting from a pilot study: Description of the post-traumatic psycholinguistic syndrome. European Journal of Trauma \& Dissociation, 100167. https://doi.org/10.1016/i.ejtd.2020.100167

Baldwin, J. R., Reuben, A., Newbury, J. B., \& Danese, A. (2019). Agreement Between

Prospective and Retrospective Measures of Childhood Maltreatment: A Systematic Review and Meta-analysis. JAMA Psychiatry, 76(6), 584-593.

https://doi.org/10.1001/jamapsychiatry.2019.0097

Bifulco, A., Bernazzani, O., Moran, P. M., \& Ball, C. (2000). Lifetime stressors and recurrent depression: preliminary findings of the Adult Life Phase Interview (ALPHI). Social Psychiatry and Psychiatric Epidemiology, 35, 264-275. https://doi.org/10.1007/s001270050238

Bifulco, A., Brown, G. W., Lillie, A., \& Jarvis, J. (1997). Memories of childhood neglect and abuse: Corroboration in a series of sisters. Journal of Child Psychology and Psychiatry, 38, 365-374. https://doi.org/10.1111/j.1469-7610.1997.tb01520.x

Bifulco, A., \& Moran, P. (1998). Wednesday's Child: Research into womens experience of neglect and abuse in childhood and adult depression. London, New York: Routledge.

Bifulco, A., \& Thomas, G. (2012). Understanding Adult Attachment in Family Relationships: Research, Assessment and Intervention. London: Routledge.

Collins, N. L., \& Read, S. J. (1990). Adult attachment, working models, and relationship quality in dating couples. Journal of Personality and Social Psychology, 58( 4), 644-663.

Dong, M., Giles, W. H., Felitti, V. J., Dube, S. R., Williams, J. E., Chapman, D. P., \& Anda, R. F. (2004). Insights into causal pathways for ischemic heart disease: adverse chldhood experiences study. Circulation, 110(13), 1761-1766. https://doi.org/10.1161/01.CIR.0000143074.54995.7F

Felitti, V. J. (2002). The Relationship of Adverse Childhood Experiences to Adult Health: Turning gold into lead. Permanente Journal, 6(1), 44-47.

First, M., Gibbon, M., Spitzer, R., \& Williams, J. (1996). Users guide for SCID. New York: Biometrics Research Dept.

Fonagy, P., Gergely, G., Jurist, E. L., \& Target, M. (2002). Affect-regulation, mentalisation and the development of the self. New York, NY: Other Press.

Francis, M. E., \& Pennebaker, J. W. (1992). Putting Stress into Words: The Impact of Writing on Physiological, Absentee, and Self-Reported Emotional Well-Being Measures. American Journal of Health Promotion, 6(4), 280-287. https://doi.org/10.4278/0890-1171-6.4.280

George, C., Kaplan, N., \& Main, M. (1984). Attachment Interview for Adults., University of California, Berkeley.

Grice, P. (1989). Studies in the Way of Words: Harvard University Press.

Herman, J. L. (1992). Trauma and recovery. London, England UK: Pandora (HarperCollinsPublishers).

Hesse, E. (2008). The Adult Attachment Interview: Protocol, method of analysis, and empirical studies. In Handbook of attachment: Theory, research, and clinical applications, 2nd ed. (pp. 552-598). New York, NY, US: The Guilford Press.

Huemer, J., Nelson, K., Karnik, N., Völkl-Kernstock, S., Seidel, S., Ebner, N., . . Skala, K. (2016). Emotional expressiveness and avoidance in narratives of unaccompanied refugee 
minors. European Journal of Psychotraumatology, 7(1), 29163.

https://doi.org/10.3402/ejpt.v7.29163

Infurna, M. R., Reichl, C., Parzer, P., Schimmenti, A., Bifulco, A., \& Kaess, M. (2016).

Associations between depression and specific childhood experiences of abuse and neglect:

A meta-analysis. Journal of Affective Disorders, 190, 47-55.

http://dx.doi.org/10.1016/j.jad.2015.09.06

Main, M., \& Hesse, E. (1990). Parents' unresolved traumatic experiences are related to infant disorganized attachment status: Is frightened and/or frightening parental behavior the linking mechanism? In M. T. Greenberg, Cicchetti, D., Cummings, E.M. (Eds.), The John D. and Catherine T. MacArthur Foundation series on mental health and development. Attachment in the preschool years: Theory, research, and intervention (pp. 161-182 ). Chicago: University of Chicago Press.

Main, M., Kaplan, N., \& Cassidy, J. (1985). Security in infancy, childhood and adulthood: A move to the level of representation. In I. Bretherton \& E. Waters (Eds.), Growing points of attachment theory and research. Chicago: University of Chicago.

McKinnon, A., Brewer, N., Meiser-Stedman, R., \& Nixon, R. (2017). Trauma memory characteristics and the development of acute stress disorder and post-traumatic stress disorder in youth. Journal of Behavior Therapy and Experimental Psychiatry, 54, 112-119.

Neuner, F., Schauer, M., Klaschik, C., Karunakara, U., \& Elbert, T. (2004). A comparison of narrative exposure therapy, supportive counseling, and psychoeducation for treating posttraumatic stress disorder in an african refugee settlement. Journal of Consultative Clinical Psychology, 72, 579-587.

Newbury, J. B., Arseneault, L., Moffitt, T. E., Caspi, A., Danese, A., Baldwin, J. R., \& Fisher, H. L. (2018). Measuring childhood maltreatment to predict early-adult psychopathology: Comparison of prospective informant-reports and retrospective self-reports. Journal of Psychiatric Research, 96, 57-64. https://doi.org/10.1016/j.jpsychires.2017.09.020

Nikro, N. S. (2019). Milieus of Rememory: Relationalities of Violence, Trauma, and Voice: Cambridge Scholars Publishing.

ONS. (2020). Crime Survey England \& Wales 2020: Child abuse extent and nature, England and Wales. Retrieved from:

https://www.ons.gov.uk/peoplepopulationandcommunity/crimeandjustice/articles/childabuse extentandnatureenglandandwales/yearendingmarch2019

Pennebaker, J. W. (1993). Putting stress into words: Health, Linguistic and therapeutic implications. Behavioral Research Therapy, 31, 539-548. https://doi.org/10.1016/00057967(93)90105-4

Reuben, A., Moffitt, T. E., Caspi, A., Belsky, D. W., Harrington, H., Schroeder, F., . . Danese, A. (2016). Lest we forget: comparing retrospective and prospective assessments of adverse childhood experiences in the prediction of adult health. Journal of Child Psychology and Psychiatry, 57(10), 1103-1112. https://doi.org/10.1111/jcpp.1262

Van der Kolk, B. (2015). The Body Keeps the Score: Mind, Brain and Body in the Transformation of Trauma London: Penguin.

Van der Kolk, B. A., Pelcovitz, D., Roth, S., Mandel, F. S., \& et al. (1996). Dissociation, somatization, and affect dysregulation: The complexity of adaption to trauma. American Journal of Psychiatry, 153(Suppl), 83-93.

Zasiekina, L. (2014). Psycholinguistic representation of individual traumatic memory in the context of social and political ambiguity. East European Journal of Psycholinguistics, 1(2), 118-125. https://doi.org/10.5281/zenodo.45899

Zasiekina, L. (2020). Trauma, Rememory and Language in Holodomor Survivors' Narratives. Psycholinguistics, 27(1), 80-94. https://doi.org/10.31470/2309-1797-2020-27-1-80-94

Zasiekina, L., Kennison, S., Zasiekin, S., \& Khvorost, K. (2019). Psycholinguistic Markers of Autobiographical and Traumatic Memory. East European Journal of Psycholinguistics, 6(2), 119-133. https://doi.org/10.29038/eejpl.2019.6.2.zas 